\title{
Penerapan Metode Algoritma C4.5 Dalam Klasifikasi Diagnosa Penyakit Umum Menggunakan WEKA
}

\author{
Rachman Komarudin ${ }^{1}$, Puspa Vicenna Barulah Yudha ${ }^{2}$, Yana Iqbal Maulana ${ }^{3}$, Nurul Afni ${ }^{4}$, \\ Agus Salim ${ }^{5}$, Irmawati Carolina ${ }^{6}$ \\ Universitas Nusa Mandiri ${ }^{1,2}$, Universitas Bina Sarana Informatika; ${ }^{3,4,5,6}$ \\ rachman.rck@nusamandiri.ac.id ${ }^{1}$, puspavicenna95@gmail.com ${ }^{2}$ yana.yim@bsi.ac.id ${ }^{3}$, \\ nurul.nrf@bsi.ac.id ${ }^{4}$, agus.salim@bsi.ac.id ${ }^{5}$, irmawati.imc@bsi.ac.id ${ }^{6}$,
}

\begin{abstract}
Abstrak - Kurangnya pengetahuan terhadap penyakit seperti DBD,Tifus dan ISPA yang disebabkan oleh virus perlu adanya tindakan atau penanganan secara cepat. Algoritma C4.5 merupakan klasifikasi yang mendapatkan hasil pohon keputusan yang mudah diinpretasikan. Penelitian ini bertujuan untuk mengetahui gejala-gejala penyakit yang disebabkan oleh virus seperti penyakit DBD (Demam Berdarah Dengue),Tifus dan ISPA (Infeksi Saluran Pernafasan Atas) menggunakan 4 parameter yaitu jenis kelamin,usia,keluhan dan suhu tubuh. Penelitian adalah mengklasifikasikan penyakit DBD,Tifus dan ISPA. Metode penelitian yang digunakan adalah data kuantitatif. Penelitian ini datanya didapat dari data sekunder. Metode yang digunakan yaitu Algoritma C4.5. Software yang dipakai untuk melihat hasil penelitian yang dibahas yaitu: software Weka 3.9. Hasil pembahasan pada software weka 3.9, tingkat akurasi data sebesar $64.2857 \%$ atau 27 data dan dari tinggkat error sekitar $35.7134 \%$ atau 15 data. Dari data 42 jumlah kasus pasien puskesmas pujer kota bondowoso yang terkena penyakit seperti DBD, Tifus dan ISPA sehingga dapat disimpulkan bahwa yang di implementasikan kedalam software weka 3.9 dapat membantu puskesmas pujer dalam mandiagnosa penyakit umum.
\end{abstract}

Kata Kunci - Algroritma C4.5, Data Mining, Penyakit Umum, Klasifikasi).

Abstract - Lack of knowledge about diseases such as dengue fever, typhoid and ARI caused by viruses requires immediate action or treatment. The $C 4.5$ algorithm is a classification that gets decision tree results that are easy to interpret. This study aims to determine the symptoms of diseases caused by viruses such as DHF (Dengue Hemorrhagic Fever), Typhus and ARI (Upper Respiratory Tract Infection) using 4 parameters, namely gender, age, complaints and body temperature. The research is to classify the diseases of DHF, Typhus and ARI. The research method used is quantitative data. This research data obtained from secondary data. The method used is the C4.5 algorithm. The software used to view the research results discussed are: Weka 3.9 software. The results of the discussion on the Weka 3.9 software, the data accuracy rate is $64.2857 \%$ or 27 data and the error rate is around $35.7134 \%$ or 15 data. From the data of 42 cases of patients at Pujer Public Health Center in Bondowoso City who were affected by diseases such as DHF, Typhus and ISPA, it can be concluded that what is implemented into the Weka 3.9 software can help Pujer Health Center in diagnosing common diseases.

Keywords: C4.5 Algorithm, Data Mining, General Diseases, Classification).

\section{PENDAHULUAN}

Masalah kesehatan merupakan suatu masalah yang sangat kompleks, yang sangat berkaitan dengan masalah-masalah lain di luar kesehatan. Banyak faktor yang mempengaruhi kesehatan, diantaranya yaitu pengetahuan dan sikap masyarakat dalam merespon suatu penyakit.Salah satu masalah kesehatan yang banyak dialami oleh sebagian besar masyarakat di Indonesia terutama wilayah Desa Pujer adalah masalah yang menyerang sistem kekebalan tubuh yang disebabkan oleh virus, yaitu DBD (Demam Berdarah Dengue), Tifus, dan ISPA ( Infeksi Saluran Pernafasan Atas). Penyakit yang disebabkan oleh virus biasanya dipengaruhi oleh banyak faktor. Diantaranya, faktor lingkungan dan kebiasaan hidup sehari-hari. DBD (Demam Berdarah Dengue) atau dengan nama lain DHF (Dengue Haemorrahagic Fever) merupakan salah satu dari beberapa penyakit menular yang menjadi masalah kesehatan di dunia terutama negara indonesia. Sejak tahun 1968 di Surabaya, muncul masalah DBD tercatat 334.685 kasus DBD. Penderita yang meninggal 3.092 orang Selama 9 tahun. DBD biasanya terjadi pada awal musim hujan yang sering terjadi. (Fakhriadi et al., 2015). salmonella typhimurium menjadi penyebab penyakit sistemik akut atau demam tifoid. 16 juta kasus setiap tahunnya diperkirakan Insidensi demam tifoid terjadi. dalam setiap tahun 600.000 orang meninggal karena penyakit ini. penyakit tifus atau demam tifoid merupakan penyakit endemik diindonesia dan menjadi masalah kesehatan yang serius. Insidensi rata-rata mencapai 650 kasus per 100.000 penduduk di Indonesia, dengan mortalitas rata-rata bervariasi dari 3,1 - 10,4\% (Ihsan \& Wajhillah, 2015) . 
Infeksi Saluran Pernapasan Akut (ISPA) atau yang kita sering sebut ISPA merupakan penyakit yang umum terjadi pada semua kategori umur, terutama pada anakanak. Ada beberapa variasi Tingkat keparahan penyakit ISPA dari faringitas ringan, pneumonia bahkan sampai pada kematian. Pada tingkat morbiditas dan mortalitas Penyakit ISPA sangat berpengaruh besar, karena salah satu penyakit infeksi menular di dunia (Br. Tarigan et al., 2017). Berdasarkan pengambilan data yang sudah ada dan latar belakang tersebut, penulis akan mencoba mengklasifikasikan penyakit Thypoid, Fever, DHF, Insfeksi Saluran Penapasan Atas (ISPA) dengan menerapkan metode Algoritma C4.5.

\section{METODOLOGI PENELITIAN}

\section{Metode Algoritma C4.5}

Algoritma C4.5 merupakan kelompok algoritma Decision Tree (Pohon Keputusan). Algoritma ini mempunyai input berupa tranning samples dan samples. Training sample berupa data contoh yang akan digunakan untuk membangun sebuah tree yang telah diuji kebenarannya. Sedangkan parameter dalam melakukan klasifikasi data menggunakan field-field data atau sample (Ihsan \& Wajhillah, 2015).

Adapun Tahapan-tahapan yang digunakan untuk menyelesaikan Algoritma C4.5 dapat dilihat pada Gambar 1:

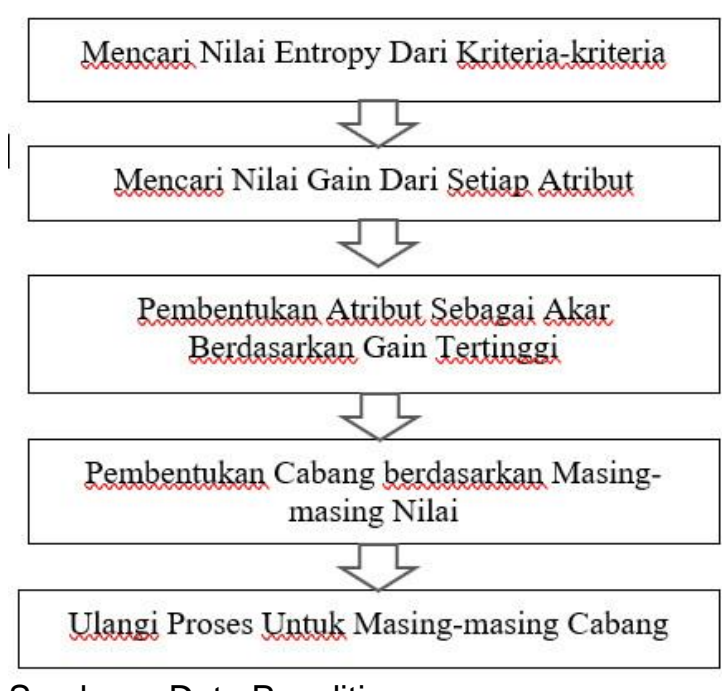

Sumber : Data Penelitian

Gambar 1. Algoritma Penyelesaian Algoritma C4.5

Dalam langkah pertama untuk menacri nilai Entropy dan Gain menggunakan rumus:

1. Entropy

$$
\operatorname{Entropy}(S)=\sum_{i=1}^{n}-p i * \log 2 p i \ldots
$$

2. Gain

$$
\begin{aligned}
\operatorname{Gain}(S, A)= & \operatorname{Entropy}(S)-\sum_{i=1}^{n} \frac{|S i|}{|S|} * \\
& \operatorname{Entropy}(S i) \ldots(2)
\end{aligned}
$$

\section{Pohon keputusan}

Salah satu metode klasifikasi yang paling popular karena mudah untuk diinterprestasi oleh manusia adalah Pohon keputusan. Konsep dari pohon keputusan adalah mengubah data menjadi pohon keputusan dan aturan-aturan keputusan. Mem-break down proses pengambilan keputusan yang kompleks menjadi lebih simple merupakan manfaat utama dari penggunaan pohon keputusan, sehingga dalam pengambil keputusan lebih menginterpretasikan solusi dari permasalahan. Selain hal tersebut Pohon keputusan dapat digunakan untuk mengeksplorasi data, menemukan hubungan tersembunyi antara jumlah calon variabel input dengan sebuah variabel target (Wulandari, 2017).

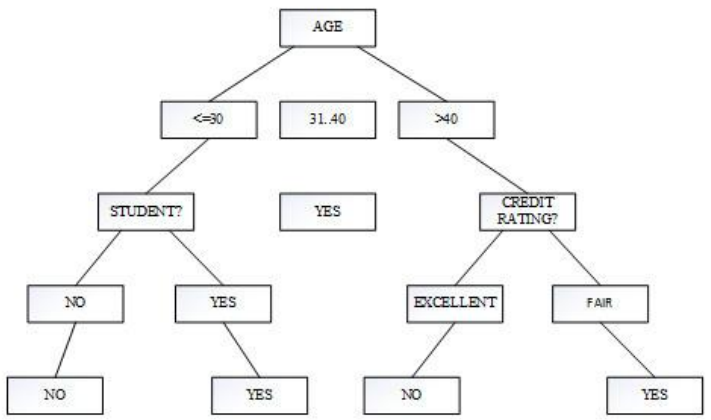

Sumber : Data Penelitian

Gambar 2. Model Pohon Keputusan

3. Tahapan Penelitian

a. Melakukan Studi Pustaka

Mempelajari berbagai sumber pustaka yang akan digunakan sebagai kajian teori dalam penelitian ini yang antara lain berasal dari buku dan jurnal penelitian.

b. Menentukan Metode Data Mining

Metode algoritma C4.5 menjadi pilihan penulis, dalam penelitian. Karena algoritma C4.5 dapat melakukan transformasi atau mengubah nilai atribut ke dalam bentuk data yang sesuai agar dapat diproses.

c. Melakukan Tahapan Metode Klasifikasi

Tahapan menggunakan metode klasifikasi menggunakan algoritma C4.5 untuk memperoleh hasil penelitian antara lain:

1). Tahap Pengumpulan Data

Tahap ini peneliti melakukan pengumpulan data yang dilakukan dengan benar. Karena tahap ini sangat berpengaruh terhadap hasil penelitian. Peneliti mendapatkan data dari database UPTD Puskesmas Pujer Bondowoso.

2). Tahap Seleksi Data

Tahap ini dilakukan selekse terhadap data database exel. Karena data yang diperoleh tidak semua digunakan, dipilih sesuai atribut atau variabel yang dibutuhkan dalam penelitian dengan melakukan seleksi data sehingga menjadi dataset. Sebagai contoh pada penelitian ini atribut atau variabel yang dipilih adalah jenis kelamin, usia, keluhan, dan suhu 
tubuh. Pada tahap seleksi untuk data yang null, data tidak valid, dan data yang ganda akan dihilangkan. Karena data yang kosong ataupun tidak valid akan berpengaruh pada hasil yang diperoleh. Kemudian data akan diolah menggunakan Microsoft Office Exel 2010.

3). Tahap Pengolahan Data

Setelah semua data yang diperlukan telah dipilih, maka tahap penelitian selanjutnya yaitu pengolahan data. Proses mengubah nilai atribut data ke dalam bentuk data yang sesuai atau tranformasi data akan dilakukan akan diakukan pada tahap ini agar dapat diproses menggunakan algoritma C4.5. Dengan menggunakan rumus 1 :

$\operatorname{Entropy}(S)=\sum_{i=1}^{n}-p i * \log 2 p i$

Dan rumus yang ke 2 :

$\operatorname{Gain}(S, A)=\operatorname{Entropy}(S)-\sum_{i=1}^{n} \frac{|S i|}{|S|} * \operatorname{Entropy}(S i)$

4). Tahap Pengujian Data

Pada tahap pengujian hasil akan dilakukan pengujian data baik secara manual dengan menggunakan algoritma C4.5 dan menggunakan software WEKA (Waikato Environmet for Knowledge Analysis).

5). Kesimpulan Penelitian

Kesimpulan merupakan langkah terakhir dari sebuah penelitian yang diambil berdasarkan analisa data dan diperiksa sesuai maksud dan tujuan peneliti sehingga menghasilkan jawaban terhadap rumusan masalah serta memberikan informasi mengenai solusi masalah yang bermanfaat untuk klasifikasi penyakit di UPT Puskesmas Pujer Bondowoso.

\section{HASIL DAN PEMBAHASAN}

Dari data sampel yang sudah di dapatkan sebanyak 42 sampel keseluruhan penyakit maka akan di hitung jumlah kasus dari setiap data dengan hasil rekapitulasi pada Tabel 1 Hasil Rekapitulasi.

Menghitung jumlah kasus, yaitu jumlah kasus untuk keputusan "Typoid Fever", jumlah kasus untuk keputusan "Demam berdarah (DHF)", jumlah kasus untuk keputusan "Infreksi Saluran Pernafasan Atas (ISPA)", dan perhitungan nilai entrophy dari semua kasus yang dibagi berdasarkan kriteria jenis kelamin dengan atribut laki-laki dan perempuan, kriteria usia dengan atribut anak, remaja, dan dewasa, kriteria keluhan memiliki atribut sakit kepala, batuk berdahak, dan $\mathrm{Bb}$ turun, dan pada kriteria suhu memiliki atribut tinggi, sedang, dan rendah. Menggunakan rumus Entropy dan Gain.

\section{A. Nilai Entrophy}

a. Entrophy Total

$$
\begin{aligned}
& \text { Entropy }(S)=\sum_{i=1}^{n}-p i * \log 2 p i \\
& =\quad\left(-\frac{20}{42} \cdot \log 2\left(\frac{20}{42}\right)\right)+\left(-\frac{11}{42} \cdot \log 2\left(\frac{11}{42}\right)\right)+ \\
& \quad\left(-\frac{11}{42} \cdot \log 2\left(\frac{11}{42}\right)\right) \\
& =0.509709+0.506231+0.506231 \\
& =1.522173
\end{aligned}
$$

b. Entrophy Jenis Kelamin

1. Laki-laki

$$
\operatorname{Entropy}(S)=\sum_{i=1}^{n}-p i * \log 2 p i
$$

$$
\begin{aligned}
\left(-\frac{12}{24} \cdot \log 2\left(\frac{12}{24}\right)\right)+ & \left(-\frac{6}{24} \cdot \log 2\left(\frac{6}{24}\right)\right)+ \\
& \left(-\frac{6}{24} \log 2\left(\frac{6}{24}\right)\right)
\end{aligned}
$$

$$
\begin{aligned}
& =0.5+0.5+0.5 \\
& =1.5
\end{aligned}
$$

2. Perempuan

$$
\begin{aligned}
& \operatorname{Entropy}(S)=\sum_{i=1}^{n}-p i * \log 2 p i \\
&=\left(-\frac{5}{18} \log 2\left(\frac{5}{18}\right)\right) \\
&\left.\left(-\frac{8}{18} \cdot \log 2\left(\frac{8}{18}\right)\right)+\left(-\frac{5}{18}\right)\right)+ \\
&=0.519966+0.513332+0.513332 \\
&=1.546632
\end{aligned}
$$

c. Entrophy Usia

1. Anak

$$
\begin{aligned}
& \text { Entropy }(S)=\sum_{i=1}^{n}-p i * \log 2 p i \\
= & \left(-\frac{2}{6} \cdot \log 2\left(\frac{2}{6}\right)\right)+\left(-\frac{3}{6} \cdot \log 2\left(\frac{3}{6}\right)\right)+ \\
& \left(-\frac{1}{6} \log 2\left(\frac{1}{6}\right)\right) \\
= & 0.528320+0.5+0.430827 \\
= & 1.459148
\end{aligned}
$$

2. Remaja

$$
\begin{aligned}
& \text { Entropy }(S)=\sum_{i=1}^{n}-p i * \log 2 p i \\
&=\left(-\frac{5}{10} \cdot \log 2\left(\frac{5}{10}\right)\right)+\left(-\frac{3}{10} \cdot \log 2\left(\frac{3}{10}\right)\right)+ \\
&\left.\left(\frac{2}{10}\right)\right) \\
&=0.5+0.521089+0.464385 \\
&=1.485475
\end{aligned}
$$


3. Dewasa

$$
\begin{aligned}
\text { Entropy }(S) & =\sum_{i=1}^{n}-p i * \log 2 p i \\
& ={ }^{\left(-\frac{13}{26} \cdot \log 2\left(\frac{13}{26}\right)\right)+}\left(-\frac{5}{26} \cdot \log 2\left(\frac{5}{26}\right)\right)+ \\
& \left(-\frac{8}{26} \log 2\left(\frac{8}{26}\right)\right) \\
= & 0.5+0.457406+0.523212 \\
= & 1.480618
\end{aligned}
$$

d. Entrophy Keluhan

1. Sakit Kepala

$$
\begin{gathered}
\text { Entropy }(S)=\sum_{i=1}^{n}-p i * \log 2 p i \\
\left.={ }^{=}-\frac{6}{15} \cdot \log 2\left(\frac{6}{15}\right)\right)+\left(-\frac{4}{15} \cdot \log 2\left(\frac{4}{15}\right)\right)+ \\
\left(-\frac{5}{15} \log 2\left(\frac{5}{15}\right)\right) \\
=0.528771+0.508504+0.528320 \\
=1.565596
\end{gathered}
$$

2. Batuk Berdahak

$$
\begin{aligned}
\text { Entropy }(S) & =\sum_{i=1}^{n}-p i * \log 2 p i \\
& ={ }^{\left(-\frac{5}{12} \cdot \log 2\left(\frac{5}{12}\right)\right)+}+\left(-\frac{3}{12} \cdot \log 2\left(\frac{3}{12}\right)\right)+ \\
& \left(-\frac{4}{12} \log 2\left(\frac{4}{12}\right)\right) \\
= & 0.526264+0.5+0.528320 \\
= & 1.554585
\end{aligned}
$$

3. Bb Turun

$$
\begin{aligned}
& \operatorname{Entropy}(S)=\sum_{i=1}^{n}-p i * \log 2 p i \\
& \left(-\frac{7}{15} \cdot \log 2\left(\frac{7}{15}\right)\right)+\left(-\frac{3}{15} \cdot \log 2\left(\frac{3}{15}\right)\right)+ \\
& \left(-\frac{5}{15} \log 2\left(\frac{5}{15}\right)\right) \\
& =0.513116+0.464385+0.528320 \\
& =1.505823
\end{aligned}
$$

e. Entrophy Suhu

1. Tinggi

$$
\begin{aligned}
& \text { Entropy }(S)=\sum_{i=1}^{n}-p i * \log 2 p i \\
= & \left(-\frac{8}{14} \cdot \log 2\left(\frac{4}{14}\right)\right) \\
\left(-\frac{8}{14} \cdot \log 2\left(\frac{8}{14}\right)\right)+ & \left(-\frac{2}{14}\right)+ \\
= & 0.461345+0.401050+0.516387 \\
= & 1.378783
\end{aligned}
$$

2. Sedang

$$
\begin{aligned}
& \operatorname{Entropy}(S)=\sum_{i=1}^{n}-p i * \log 2 p i \\
& \left(-\frac{7}{18} \cdot \log 2\left(\frac{7}{18}\right)\right)+\left(-\frac{6}{18} \cdot \log 2\left(\frac{6}{18}\right)\right)+ \\
& \left(-\frac{5}{18} \log 2\left(\frac{5}{18}\right)\right) \\
& =0.529888+0.528320+0513332 \\
& =1.571542
\end{aligned}
$$

3. Rendah

$$
\begin{aligned}
\text { Entropy }(S) & =\sum_{i=1}^{n}-p i * \log 2 p i \\
& ={ }^{\left(-\frac{5}{10} \cdot \log 2\left(\frac{5}{10}\right)\right)+}\left(-\frac{3}{10} \cdot \log 2\left(\frac{3}{10}\right)\right)+ \\
& \left(-\frac{2}{10} \log 2\left(\frac{2}{10}\right)\right) \\
= & 0.5+0.521089+0464385 \\
= & 1.485475
\end{aligned}
$$

\section{B. Nilai Gain}

1. Gain Jenis Kelamin

$$
\begin{aligned}
& \text { Gain }(\text { total }, j \mathrm{k})=1.522173-\sum_{\mathrm{i}=0}^{\mathrm{n}}\left(\left(\frac{24}{42}\right) \star 1.5\right)+ \\
& \left(\left(\frac{18}{42}\right){ }^{\star} 1.546632\right) \\
& =1.327872
\end{aligned}
$$

2. Gain Usia

Gain (total,usia) $=1.522173-\sum_{i=0}^{n}\left(\left(\frac{6}{42}\right) * 1.459148\right)+$ $\left(\left(\frac{10}{42}\right) * 1.485475\right)+\left(\left(\frac{26}{42}\right) * 1.480618\right)$

$$
=2.583981
$$

3. Gain Keluhan

Gain (total,keluhan) $=1.522173-\sum_{i=0}^{n}\left(\left(\frac{15}{42}\right) * 1.565596\right)+$

$\left(\left(\frac{12}{42}\right) * 1.554585\right)+\left(\left(\frac{15}{42}\right) * 1.505823\right)$

$$
=1.944993
$$

4. Gain Suhu

Gain $($ total,suhu $)=1.522173-\sum_{i=0}^{n}\left(\left(\frac{14}{42}\right) * 1.378783\right)+$

$\left(\left(\frac{18}{42}\right) * 1.571542\right)+\left(\left(\frac{10}{42}\right) * 1.485475\right)$ $=2.089781$

Setelah nilai gain didpat dari hasil perhitungan masing-masing nilai entrophy perkriteria, Hasil perhitungan dapat dilihat pada tabel 2 Hasil Rekapitulasi Entropy dan Gain. 
Pada tabel 2 Hasil Rekapitulasi Entropy dan Gain menunjukkan bahwa kriteria "Usia" memiliki nilai gain tertinggi. Sehingga untuk kriteria usia akan menjadi node pertama pada pohon keputusan. Gambar 3 menunjukkan pohon keputusan:

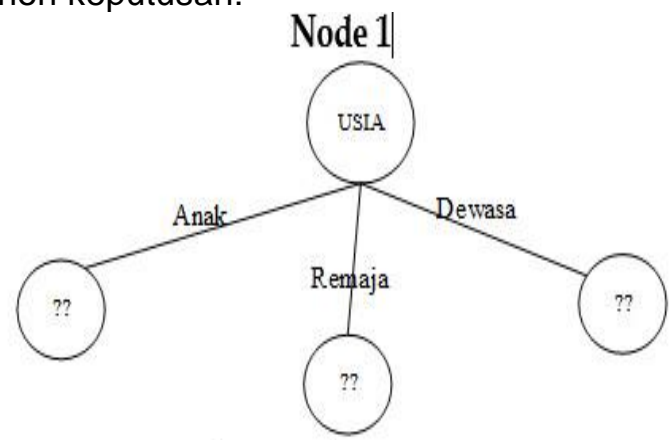

Sumber : Data Penelitian

Gambar 3. Pohon Keputusan

Setelah mendapatkan hasil pohon keputusan seperti diatas kita tahu yg menjadi akar pertama dari pohon tersebut. Dan untuk mengetahui hasil keseluruhan dari phon tersebut kita harus melakukan perhitungan ulang untuk mendapatkan hasil node berikutnya.

Dengan cara yang sama kita ulangi perhitungan nilai entropy dan gain dari setiap atribut yang didapatkan sepeti pada atribut Anak, Remaja, Dewasa. Kita harus mencari nilai Gain yang tertinngi sehingga bisa dihitung nilainya.

Setelah melakukan perhitungan keseluruhan maka akan didapat hasil pohon keputusan keseluruhan seperti ditunjukkan pada Gambar 4:

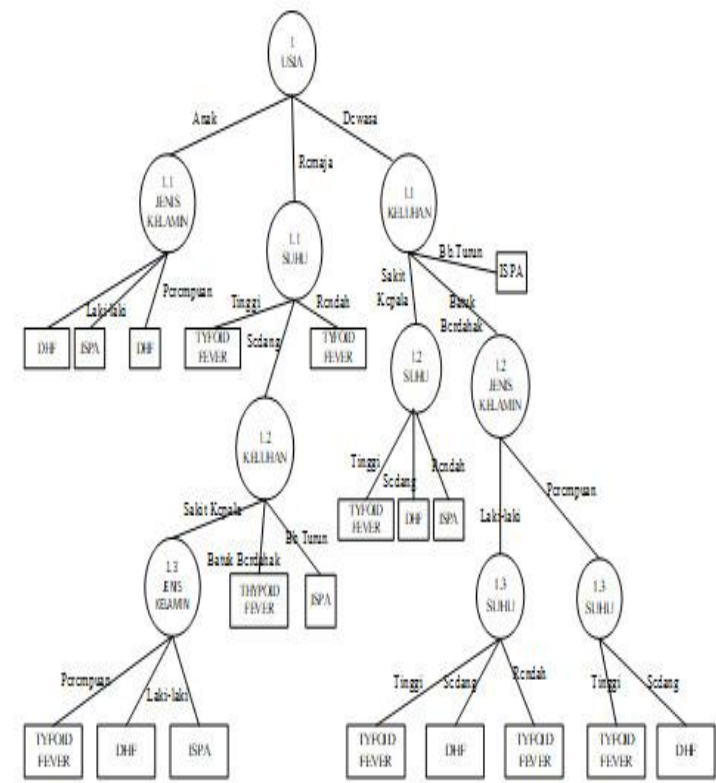

Sumber : Data Penelitian

Gambar 4. Pohon Keputusan
Proses Data Menggunakan Aplikasi Weka 3.9

Pertama-tama klik aplikasi weka 3.9 maka akan muncul tampilan seperti :

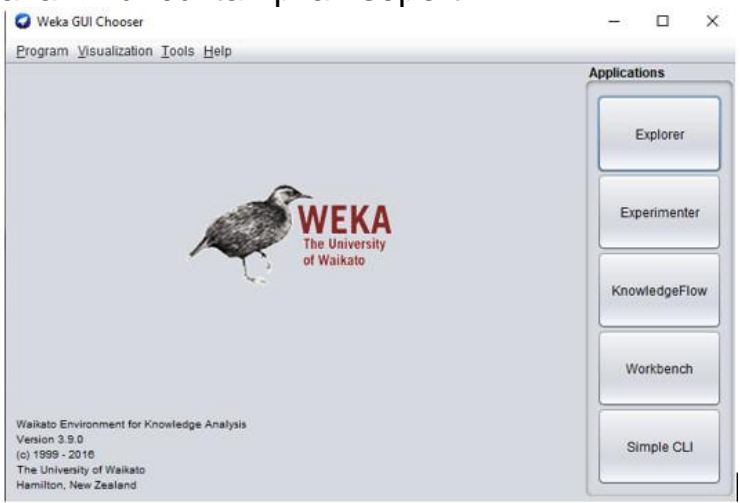

Sumber: software weka 3.9

Gambar 5 Tampilan Interface Pada Weka 3.9

Kemudian klik Explorer pada command button diatas, lalu klik open file yang ada di pojok kiri atas. Cari file yang akan diuji validasinya dengan format file .csv seperti gambar dibawah.

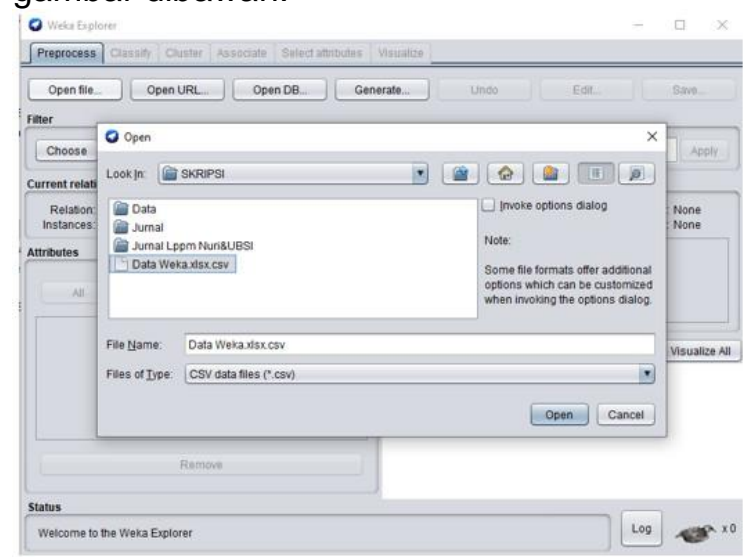

Sumber: software weka 3.9

Gambar 6 Tampilan Insert File Langkah selanjutnya yaitu klik open maka akan muncul tampilan sebagai berikut

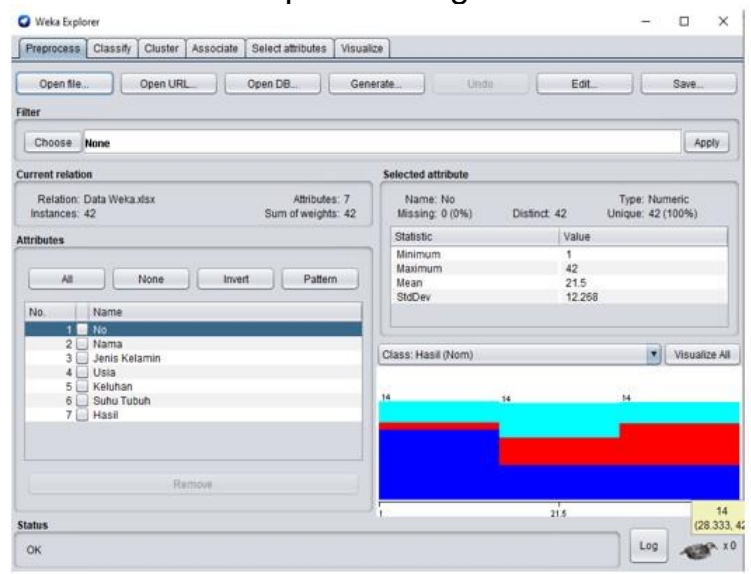

Sumber: software weka 3.9

Gambar 7 Tampilan Proses Pengujian Jangan lupa pada command button class, pilih class yang sudah ditentukan 
sebelumnya. Kemudian klik button classify yang ada dipojok kiri atas. Lalu klik Choose, maka akan muncul tampilan seperti di bawah ini.

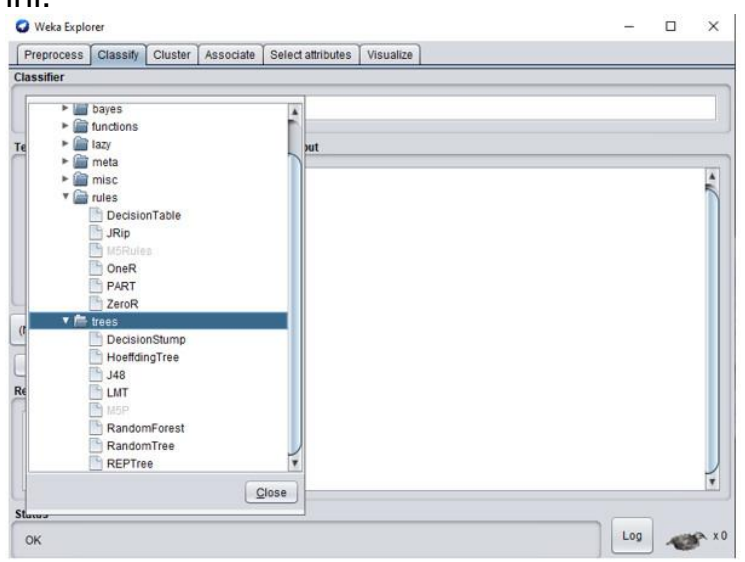

Sumber: software weka 3.9

Gambar 8 Tampilan Pemilihan Metode Algoritma C4.5

Pilih trees lalu klik J48 pada aplikasi weka ini metode algoritma C4.5 adalah J48.

Langkah berikutnya klik use tranning set yang artinya semua data yang diinput tadi akan diujikan semuanya. Pada tulisan J48-C 0.25 M 2 yang ada disamping choose lalu pilih true pada unpruned. Kemudian klik Ok maka tulisan J48-C $0.25-\mathrm{M} 2$ berubah menjadi J48 -U -M 2 seperti gambar dibawah ini:

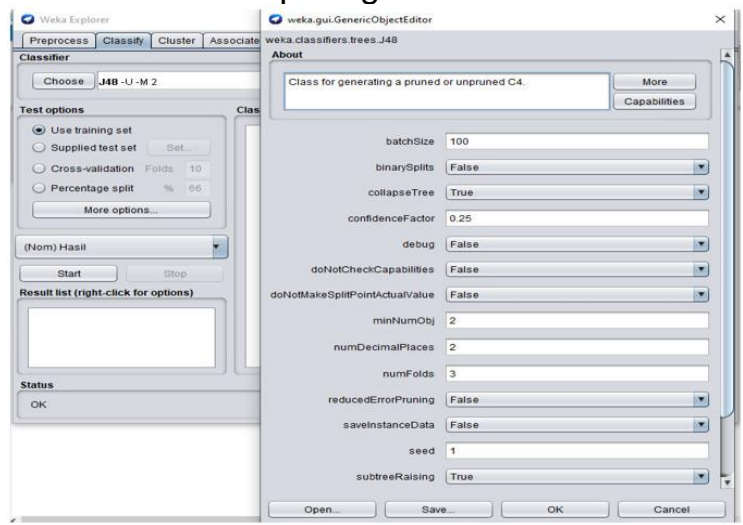

Sumber: software weka 3.9

Gambar 9 Tampilan Pemilihan Unpruned Klik Ok kemudian Klik Start maka akan muncul tampilan seperti berikut ini:

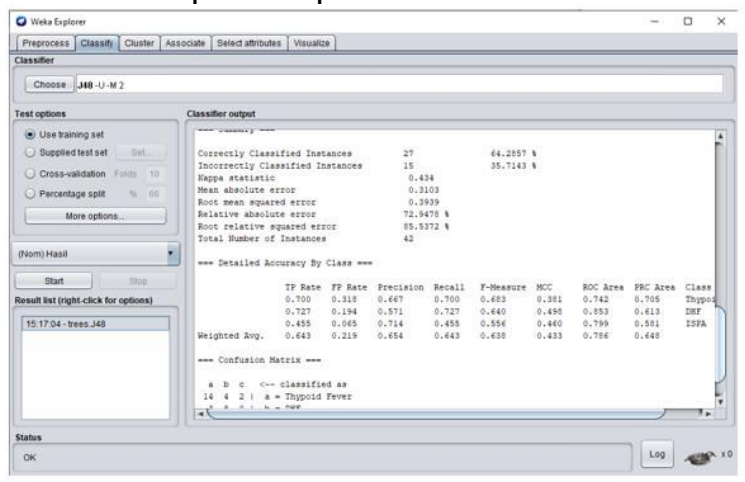

Sumber: software weka 3.9

Gambar 10 Tampilan Hasil Analisa Classify
Dimana pada script di samping bahwa tingkat pengklasifikasian yang benar adalah $64,2857 \%$ sedangkan tingkat kesalahanya adalah sekitar $35,7143 \%$.

Untuk melihat hasil pohon keputusannya pada kolom results list klik kanan pada trees J48 seperti gambar dibawah ini:

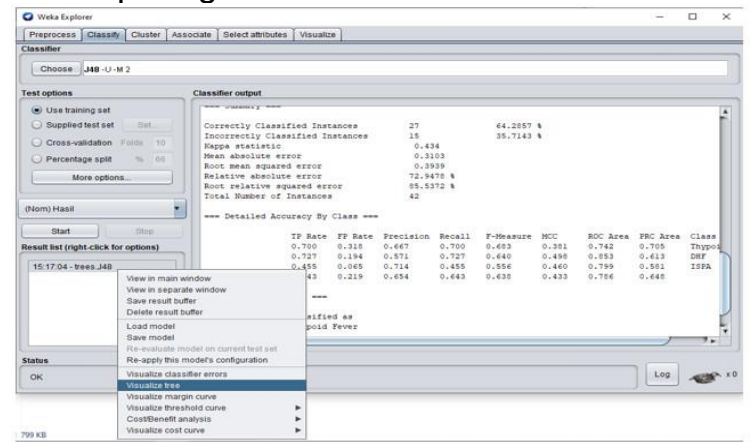

Sumber: software weka 3.9

Gamber 11 Tampilan Proses Visualize Tree Pada visualize tree kemudian akan muncul pohon keputusan dari hasil classifikasi data yang telah dilakukan berikut hasil pohon keputusan

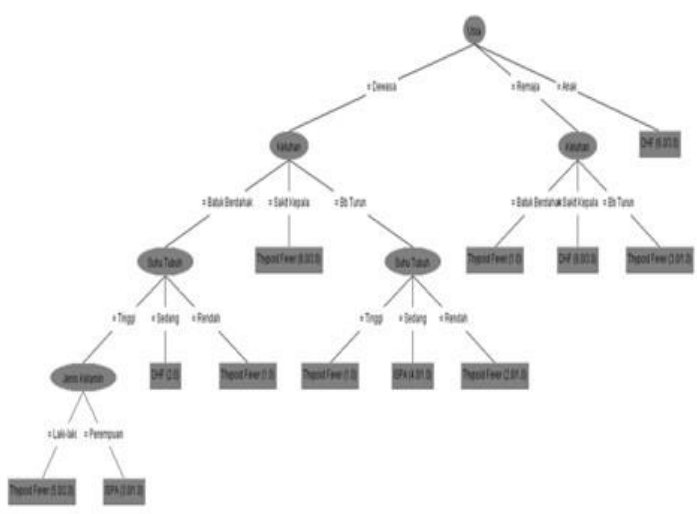

Sumber : Data Penelitian software weka 3.9 Gambar 12. Hasil Pohon Keputusan Aplikasi Weka

Gambar diatas merupakan hasil pengujian menggunakan software Weka 3.9. Dapat dilihat bahwa dari hasil pengujian software kriteria "usia" yang menjadi akar pertama dari pohon keputusan. Pada node akar "usia" yang memiliki hasil diagnosa adalah atribut anak yaitu DHF. Pada atribut remaja kriteria "keluhan" memiliki hasil diagnosa di atribut batuk berdahak dan Bb.Turun diagnosanya typhoid fever dan atribut sakit kepala diagnosanya DHF.

Sedangkan pada atribut dewasa "keluhan" menjadi kriteria. Pada tahap selanjutnya di kriteria "keluhan" atribut sakit kepala sudah memiliki diagnosa typhoid fiver, sedangkan atribut Bb.Turun pada kriteria "suhu" atribut tinggi diagnosanya typhoid fever, atribut sedang diagnosanya ISPA, dan atribut rendah diagnosanya typhoid fever. 
Kriteria "keluhan" pada atribut batuk berdahak "suhu tubuh" yang memiliki diagnosa pasti yaitu atribut sedang diagnosanya DHF, atribut rendah diagnosanya typhoid fever, dan atribut tinggi memiliki kriteria "jenis kelamin" yang hasil diagnosanya pasti, pada atribut laki-laki diagnosanya typhoid fever, dan atribut perempuan diagnosanya ISPA.

Dari hasil keseluruhan didapat tingkat akurasi kebenaran sebesar $64.2857 \%$ atau 27 data sedangkan tingkat error sekitar $35.7134 \%$ atau 15 data.

Tabel 1. Hasil Rekapitulasi

\begin{tabular}{|c|c|c|c|c|c|c|c|}
\hline Node & & $\begin{array}{c}\text { Jumlah } \\
\text { kasus }(\mathrm{S})\end{array}$ & $\begin{array}{l}\text { Typoid } \\
\text { Fever }\end{array}$ & $\begin{array}{c}\text { Demam } \\
\text { berdarah } \\
(\mathrm{DHF})\end{array}$ & $\begin{array}{c}\text { Infeksi } \\
\text { Saluran } \\
\text { Pernafasan } \\
\text { Atas (ISPA) }\end{array}$ & Entrophy & Gain \\
\hline \multirow[t]{16}{*}{1} & Total & 42 & 20 & 11 & 11 & & \\
\hline & Jenis Kelamin & & & & & & \\
\hline & Laki - Laki & 24 & 12 & 6 & 6 & & \\
\hline & Perempuan & 18 & 8 & 5 & 5 & & \\
\hline & Usia & & & & & & \\
\hline & Anak & 6 & 2 & 3 & 1 & & \\
\hline & Remaja & 10 & 5 & 3 & 2 & & \\
\hline & Dewasa & 26 & 13 & 5 & 8 & & \\
\hline & Keluhan & & & & & & \\
\hline & Sakit Kepala & 15 & 6 & 4 & 5 & & \\
\hline & Batuk Berdahak & 12 & 5 & 3 & 4 & & \\
\hline & Bb Turun & 15 & 7 & 3 & 5 & & \\
\hline & Suhu & & & & & & \\
\hline & Tinggi & 14 & 8 & 2 & 4 & & \\
\hline & Sedang & 18 & 7 & 6 & 5 & & \\
\hline & Rendah & 10 & 5 & 3 & 2 & & \\
\hline
\end{tabular}

sumber : Data Penelitian

Tabel 2. Hasil Rekapitulasi Entropy dan Gain

\begin{tabular}{|c|c|c|c|c|c|c|c|}
\hline Node & & $\begin{array}{c}\text { Jumlah } \\
\text { kasus }(\mathrm{S})\end{array}$ & $\begin{array}{l}\text { Typoid } \\
\text { Fever }\end{array}$ & $\begin{array}{c}\text { Demam } \\
\text { berdarah } \\
(\mathrm{DHF})\end{array}$ & $\begin{array}{c}\text { Infeksi } \\
\text { Saluran } \\
\text { Pernafasan } \\
\text { Atas (ISPA) }\end{array}$ & Entrophy & Gain \\
\hline \multirow[t]{16}{*}{1} & Total & 42 & 20 & 11 & 11 & 1.522173 & \\
\hline & Jenis Kelamin & & & & & & 1.327872 \\
\hline & Laki - Laki & 24 & 12 & 6 & 6 & 1.5 & \\
\hline & Perempuan & 18 & 8 & 5 & 5 & 1.546632 & \\
\hline & Usia & & & & & & 2.583981 \\
\hline & Anak & 6 & 2 & 3 & 1 & 1.459148 & \\
\hline & Remaja & 10 & 5 & 3 & 2 & 1.485475 & \\
\hline & Dewasa & 26 & 13 & 5 & 8 & 1.480618 & \\
\hline & Keluhan & & & & & & 1.944993 \\
\hline & Sakit Kepala & 15 & 6 & 4 & 5 & 1.565596 & \\
\hline & Batuk Berdahak & 12 & 5 & 3 & 4 & 1.554585 & \\
\hline & $\mathrm{Bb}$ Turun & 15 & 7 & 3 & 5 & 1.505823 & \\
\hline & Suhu & & & & & & 2.089781 \\
\hline & Tinggi & 14 & 8 & 2 & 4 & 1.378783 & \\
\hline & Sedang & 18 & 7 & 6 & 5 & 1.571542 & \\
\hline & Rendah & 10 & 5 & 3 & 2 & 1.485475 & \\
\hline
\end{tabular}

sumber : Data Penelitian 


\section{KESIMPULAN}

Berdasarkan uraian dan analisi yang telah dipaparkan pada bab sebelumnya dan hasil penelitian dari data sampel yang diambil dengan mengklasifikasikan menggunakan metode Algoritma C4.5 (Decision Tree). penulis menarik kesimpulan sebagai berikut :

1. Pada pengujian manual pada node akar 1.1 masing-masing kriteria memiliki hasil diagnosa tetapi pada kriteria suhu dan kriteria keluhan ada node yang belum memiliki diagnosa yang tepat sehingga harus dihitung lagi nilai entropy dan gainnya dan mendapay diagnosa yang tepat. Sama seperti pada node 1.1 dan node 1.2 juga masih ada kriteria yang belum mendapatkan diagnosa yang tepat. Sehingga melakukan perhitungan ulang pada nilai entropy dan gain yang masih memiliki nilai. Dan pada node 1.3 (terakhir) sudah memiliki hasil diagnosa yang pasti di setiap kriteria.

2. Pada pengujian software weka 3.9 dari hasil pengujian software kriteria "usia" yang menjadi akar pertama dari pohon keputusan. Pada node akar "usia" yang memiliki hasil diagnosa adalah atribut anak yaitu DHF. Pada atribut remaja kriteria "keluhan" memiliki hasil diagnosa di atribut batuk berdahak dan $\mathrm{Bb}$.Turun diagnosanya typhoid fever dan atribut sakit kepala diagnosanya DHF. Sedangkan pada atribut dewasa "keluhan" menjadi kriteria. Pada tahap selanjutnya di kriteria "keluhan" atribut sakit kepala sudah memiliki diagnosa typhoid fiver, sedangkan atribut Bb.Turun pada kriteria "suhu" atribut tinggi diagnosanya typhoid fever, atribut sedang diagnosanya ISPA, dan atribut rendah diagnosanya typhoid fever. Kriteria "keluhan" pada atribut batuk berdahak "suhu tubuh" yang memiliki diagnosa pasti yaitu atribut sedang diagnosanya DHF, atribut rendah diagnosanya typhoid fever, dan atribut tinggi memiliki kriteria "jenis kelamin" yang hasil diagnosanya pasti, pada atribut laki-laki diagnosanya typhoid fever, dan atribut perempuan diagnosanya ISPA.

3. Dari hasil pengujian manual dan hasil pengujian pada aplikasi software weka 3.9 dengan tingkat akurasi data sebesar $64.2857 \%$ atau 27 data, dan tingkat error sekitar $35.7134 \%$ atau 15 data pada aplikasi hasi node akar pertama hasilnya sama pada krieria usia.

4. Dari hasil data 42 sampel yang terbentuk pada pohon keputusan dengan pengujian secara manual dan aplikasi software weka 3.9 dapat di informasikan bahwa kriteria usia adalah atribut yang paling berpengaruh dalam mengklasifikasikan penyakit umum berdasarkan data yang di proses dengan melihat kriteria jenis kelamin, keluhan dan suhu.

Sehingga penulis menarik kesimpulan bahwa adanya validasi (pembuktian) data dari hasil pengujian manual maupun hasil pengujian aplikasi software weka 3.9, dikarenakan hasil pohon keputusannya tidak sama.)

\section{REFERENSI}

Br. Tarigan, D. M., Dr. Rini, D. P. M. ., \& Puspita, V. (2017). Perancangan Data Mining untuk Klasifikasi Prediksi Penyakit ISPA dengan Algoritma C4.5. Computer Science and ICT, 3(1), 179-182. https://seminar.ilkom.unsri.ac.id/index.php /ars/article/view/1711

Fakhriadi, R., Yulidasari, F., \& Setyaningrum, R. (2015). Faktor risiko penyakit Demam Berdarah Dengue di Wilayah Kerja Puskesmas Guntung Payung Kota Banjarbaru (Tinjauan terhadap faktor manusia, lingkungan, dan keberadaan jentik). Jurnal Publikasi Kesehatan Masyarakat Indonesia, 2(1), 8-12. https://ppjp.ulm.ac.id/journal/index.php/JP $\mathrm{KMl} /$ article/view/2703/2353

Ihsan, \& Wajhillah, R. (2015). Penerapan Algoritma C4.5 Terhadap Diagnosa Penyakit Demam Tifoid Berbasis Mobile. Jurnal Swabumi AMIK BSI Sukabumi, III(1), $\quad$ 50-58. https://ejournal.bsi.ac.id/ejurnal/index.php/ swabumi/article/view/1006

Wulandari, R. T. (2017). Data Mining Teori dan Aplikasi Rapidminer. Yogyakarta: Gava Media. 